\title{
Peningkatan Hasil Belajar Materi Keimanan melalui Pembelajaran Kooperatif Tipe TAI (Team Assisted Individualization)
}

\author{
Atik Lestari \\ Sekolah Dasar Negeri 2 Kauman Kabupaten Boyolali \\ Email: atiklestari@gmail.com
}

\begin{abstract}
Abstrak
Penelitian ini bertujuan untuk mengetahui peningkatan hasil belajar mata pelajaran pendidikan agama islam materi iman kepada kitab-kitab Allah dengan model pembelajaran kooperatif tipe TAI (Team Assisted Individualization) kelas V SD Negeri 2 Kauman kemusu semester 1 tahun 2013/2014. Penelitian ini adalah penelitian tindakan kelas (PTK) yang menggunakan tiga siklus, masing-masing siklus memiliki empat tahap, yaitu perencanaan (planing), tindakan (acting), pengamatan (observing), dan refleksi (reflecting). Teknik analisis data yang digunakan dalam penelitian ini adalah deskriptif kualitatif dan deskriptif kuantitatif. Dalam penelitian ini terjadi peningkatan hasil belajar dari tolok ukur pencapaian $\mathrm{KKM} \geq 70$. Terjadi peningkatan ketuntasan hasil belajar siswa secara bertahap. Temuan penelitian menunjukkan bahwa penggunaan metode pembelajaran kooperatif tipe TAI yang tepat mampu meningkatkan hasil belajar. Hasil belajar siswa dapat meningkat, dilihat dari hasil tes formatif pada setiap siklus yaitu siklus I 27,78\%, siklus II 72,22\% dan siklus III 94,44\% Mengacu pada hasil penelitian peneliti menyarankan kepada para guru atau calon guru untuk selalu meningkatkan inovasi pembelajarannya dengan menggunakan media, metode dan teknik yang bervariasi. Dengan demikian dapat disimpulkan bahwa penggunaan model pembelajaran kooperatif tipe TAI (Team Assisted Individualization) dapat meningkatkan hasil belajar siswa mata
\end{abstract}


pelajaran PAI pada SD Negeri 2 Kauman Kecamatan Kemusu Kabupaten Boyolali Semester 1 tahun 2013/2014.

This study aims to determine the learning outcome of Islamic religious education Faith in Holy Book material with cooperative learning method type of TAI (Team Assisted Individualization) in class V SD Negeri 2 Kauman Kemusu at the first semester year 2013/2014. It is a classroom action research. This study use three cycles, each cycle has four phases: planning, action, observation and reflection. Data analyses by descriptive qualitative and quantitative technique. In this study, there was an increase learning outcomes gradually to passing grade (KKM) $\geq 70$. The findings indicate that the use of cooperative learning method, i.e. appropriate TAI, can improve learning outcomes. Students' learning outcomes can be improved, judging from the results of formative tests at each cycle is the first cycle of $27.78 \%, 72.22 \%$ in second cycle and the third cycle $94.44 \%$ Referring to the results of the study, the researcher suggest to teachers or prospective teachers to improve learning by using varied media, methods and techniques. It can be concluded that the use of cooperative learning method type of TAI (Team Assisted Individualization) can improve student learning outcomes in PAI subject on SD Negeri 2 Kauman Kemusu Boyolali District in the first semester at the year of 2013/2014.

Kata kunci: hasil belajar, Pendidikan Agama Islam, Team Assisted Individualization

\section{Pendahuluan}

Pendidikan adalah sebuah proses interaksi antara pendidik atau guru bertindak mendidik peserta didik. Tindak mendidik tersebut tertuju pada perkembangan siswa menjadi mandiri. Untuk dapat berkembang menjadi mandiri, siswa harus belajar (Dimyati dan Mudjiono, 2002 : 5). Proses belajar inilah memerlukan metodologi tertentu supaya mengalami peningkatan. Prose situ dilakukan oleh guru yang kemudian disebut dengan mengajar. Menurut S. Nasution (1982: 8) mengajar adalah suatu 
aktivitas mengorganisir lingkungan sebaik-baiknya dan hubungannya dengan anak sehingga terjadi proses belajar. Mengajar dan belajar adalah kesatuan utuh yang terjadi di sekolah yang dilakukan bersama-sama dan dalam waktu tertentu. Maka proses inilah melibatkan berbagai aspek baik dari guru, siswa maupun lingkungan.

Belajar menurut Dimyati dan Mudjiono (2002 : 10) adalah seperangkat proses kognitif yang mengubah sifat stimulasi lingkungan, melewati pengolahan informasi, menjadi kapabilitas baru. Agar kegiatan ini dapat diterima oleh para siswa, guru perlu berusaha membangkitkan kemauan siswa untuk belajar. Kemauan siswa dalam belajar dapat dibangkitkan melalui proses belajar mengajar yang efektif, yaitu keadaan belajar mengajar dimana siswa dapat berperan aktif dan dapat menyerap materi yang diberikan oleh guru. Kemampuan siswa dalam memahami dan menyerap materi yang diberikan kepada guru biasanya ditunjukan dengan kemampuan menjawab pertanyaan dari guru. Pertanyaan yang diberikan oleh guru dan jawaban dari siswa dapat dipakai untuk mengetahui sejauh mana materi yang diberikan dapat diterima siswa.

Proses belajar ini yang diharapkan adalah meningkatnya prestasi belajar siswa. Prestasi belajar menurut Abu Ahmadi (1988:21) adalah hasil belajar yang telah dicapai dalam suatu usaha dalam kegiatan belajar dan perwujudan prestasinya dapat dilihat dari nilai yang setiap mengikuti tes. Prestasi belajar ini akan mengalami peningkat jika guru selalu inovatif dan kreatif menentukan metode belajar. Metode belajar inilah kemudian diharapakan prestasi belajar peserta didik meningkat. 
Langkah guru dalam menetapkan metode penbelajaran yang tepat untuk menyampaikan materi pelajaran di kelas merupakan salah satu penentu keberhasilan, sehingga peningkatan hasil belajar siswa dapat dicapai. Pemilihan metode pembelajaran sangat menentukan kualitas pengajaran dalam proses belajar mengajar. Untuk mencapai tujuan penagajaran diperlukan penggunaan metode pembelajaran yang optimal. Disinilah proses kreatifitas guru sangatlah penting untuk menunjang proses belajar mengajar yang benar-benar mampu membangkitkan motivasi anak didik dan juga meningkatkan prestasi belajar mereka.

Metode pembelajaran saat ini berkembang begitu pesat dan berbagai macam. Tentu saja sebagai pendidik harus mampu memilih metode pembelajaran yang benar-benar sesuai dengan kondisi dan lingkungan sekolah dimana proses belajar mengajar dilakukan. Salah satu dari berbagai macam metode pembelajaran adalah pembelajaran kooperatif.

Pembelajaran kooperatif yang digunakan peneliti adalah tipe TAI (Team Assisted Individualization). Metode TAI merupakan metode pengajaran secara kelompok dimana terdapat seorang siswa yang lebih mampu berperan sebagai asisten yang bertugas membantu secara individual siswa lain yang kurang mampu dalam suatu kelompok. Dalam hal ini peran pendidik hanya sebagai fasilitator dan mediator dalam proses belajar mengajar. Pendidik cukup menciptakan kondisi lingkungan belajar yang kondusif bagi peserta didiknya. Pada pengajaran TAI akan memotivasi siswa saling membantu anggota kelompoknya sehingga tercipta semangat dalam sistem kompetensi. 
Mata pelajaran PAI (Pendidikan Agama Islam) dapat melatih keterampilan berpikir religius, dapat menanamkan dan mengembangkan sikap ilmiah, dapat menemukan dan memecahkan masalah baru mengenai metode ilmiah dan sebagainya. Proses pembelajaran PAI di SD Negeri 2 Kauman belum memperoleh hasil yang memuaskan, yaitu nilai siswa masih dibawah KKM (=70). Metode pembelajaran yang kurang menarik menjadi salah satu kendala yang menyebabkan prestasi belajar tidak sesuai dengan KKM. Untuk meningkat prestasi belajar tersebut melalui implementasi Metode Pembelajaran Kooperatif tipe TAI. Metode pembelajaran ini dirasa memiliki kesesuaian dengan kondisi siswa serta lingkungan sekolah.

Nilai akademik yang selama ini dibawah standar KKM diharapkan bisa meningkat karena nilai pendidikan agama islam kelas V SD Negeri 2 Kauman Kabupten Boyolali tahun ajaran 2013/2014 belum mencapai nilai KKM (70). Peneliti mengadakan penelitian untuk mengetahui apakah melalui pembelajaran kooperatif tipe TAI dapat meningkatkan hasil belajar siswa kelas V SD Negeri 2 Kauman Kabupaten Boyolali tahun ajaran 2013/2014? Penelitian ini bertujuan untuk mengetahui apakah melalui pembelajaran kooperatif tipe TAI dapat meningkatkan hasil belajar siswa kelas V SD Negeri 2 Kauman Kabupaten Boyolali Tahun Ajaran 2013/2014.

Menurut Robert E. Slavin (2009 : 1) keberadaan metode-metode pembelajaran kooperatif yang efektif kini sebenarnya akan hadir untuk berbagai keperluan pengajaran yang ada. Banyaknya pengaruh pembelajaran kooperatif yang efektif, khususnya untuk mencapai 
prestasi. Kini menjadi mungkin bagi para guru memilih metode yang sesuai dari sekian banyak metode kooperatif untuk diterapkan pada keperluan yang berbeda, dan untuk menggunakan pembelajaran kooperatif sebagai skema pengorganisasian utama dalam pengajaran di kelas, dan bukan hanya untuk kegiatan-kegiatan tertentu.

Ada banyak alasan yang membuat pembelajaran kooperatif memasuki jalur utama praktik pendidikan. Salah satunya adalah berdasar penelitian dasar yang mendukung penggunaan pembelajaran kooperatif untuk meningkatkan pencapaian prestasi dan kemandirian para siswa, dan juga akibat-akibat positif yang dapat mengembangkan hubungan antar kelompok, penerimaan terhadap teman sekelas yang lemah dalam bidang akademik, dan meningkatkan rasa harga diri. Alasan lain adalah tumbuhnya kedasaran bahwa para siswa perlu belajar.

Manusia tumbuh dan berkembang dari bayi yang tak berdaya dan dalam segala kebutuhannya bergantung pada orang lain menjadi manusia yang dapat menyesuaikan diri dengan berbagai corak ragam dari masyarakat, dari yang sedehana sampai yang modern dan kompleks. Untuk menjelaskan bagaimana proses belajar itu berlangsung, timbul berbagai teori. Menurut Nasution:1982 ada teori belajar yang didasarkan atas sosiasi, ada pula atas insight, dan prinsip yang satu tak dapat diadukan yang lain.

Robert M. Gagne membedakan 8 type belajar yakni: signal learning (belajar isyarat), stimulus response (belajar stimulus respon), chaining (rantai), verbal association (diskriminasi), concept (konsep), rule learning (belajar aturan), problem solving (memecahkan masalah). 
Alasan peneliti mengangkat masalah tersebut untuk memperbaiki nilai siswa dalam proses pembelajaran yang dilaksanakan guru belum menunjukkan hasil yang maksimal yaitu masih terdapat 10 siswa yang belum memenuhi Kriteria Ketuntasan Minimum (KKM=70). Sedangkan yang sudah mencapai hasil yang maksimal ada 8 siswa. Selain itu, alasan dijadikan Penelitian Tindakan Kelas, yakni : 1) Menggunakan metode ceramah kurang mampu membangkitkan semangat siswa dalam belajar; 2) Jika disajikan dengan metode TAI, akan lebih menarik dan mampu melatih kemampuan motorik siswa; 3) Metode TAI melatih siswa untuk berani mengemukakan pendapat dan memberikan komentar terhadap suatu masalah; 4) Siswa yang kurang mampu dalam akademik dapat diterima di dalam kelompok.

Metode pembelajaran kooperatif merupakan strategi yang mendorong siswa aktif menemukan sendiri pengetahuannya melalui ketrampilan proses (Henny, 2003:20). Metode Pembelajaran Kooperatif Tipe TAI merupakan metode pembelajaran yang membentuk kelompok kecil yang heterogen dengan latar belakang cara berfikir yang berbeda untuk saling membantu terhadap siswa yanh mebutuhkan bantuan (Suyitno, 2002:9)

Selain itu kegiatan guru sebagai usaha perbaikan pembelajaran melalui penggunaan metode TAI, diharapkan mampu meningkatkan hasil belajar dalam mata pelajaran PAI. Sehingga pada proses pembelajaran siswa antusias dan fokus pada materi yang diajarkan guru. Pendidikan Agama Islam adalah usaha-usaha secara sistematis dan pragmatis dalam membantu anak didik agar mereka hidup sesuai dengan ajaran islam 
(Zuhairani, 1983:27). Metode pembelajaran kooperatif tipe TAI (Team Assisted Individualization) diharapkan mampu meningkatkan prestasi hasil belajar PAI pada siswa kelas V SD Negeri 2 Kauman Kabupaten Boyolali.

\section{Metode Penelitian}

Rancangan penelitian yang diterapkan dalam penelitian tindakan kelas. Istilah penelitian tindakan kelas diartikan sebagai bentuk penelitian yang dilakukan oleh guru di kelasnya sendiri melalui refleksi diri dengan tujuan untuk memperbaiki kinerjanya sehingga hasil belajar siswa meningkat (Arikunto, 2006:91). Dalam penelitian tindakan kelas, tiap siklus terdiri dari perencanaan, pelaksanaan tindakan, observasi, dan refleksi. Siklus tersebut dilaksanakan dengan tujuan untuk memperbaiki prestasi belajar siswa.

\section{Paparan Deskripsi Penelitian}

Dalam penelitian ini setiap pembelajaran di gunakan lembar soal formatif untuk mengukur sejauh mana hasil belajar siswa setelah mengikuti pembelajaran Pendidikan Agama Islam dengan menerapkan metode pembelajaran kooperatif tipe TAI. Secara rinci, hasil penelitian akan diuraikan sebagai berikut.

\section{Siklus I}

Adapun dari hasil tes formatif pada siklus I ini, didapatkan hasil sebagaimana terdapat pada tabel berikut ini: 
Tabel 2.1

Hasil tes formatif pada siklus I

\begin{tabular}{|c|l|c|c|c|}
\hline No & \multicolumn{1}{|c|}{ Nama } & KKM & Nilai & Keterangan \\
\hline 1 & Any Marsela & 70 & 30 & Tidak Tuntas \\
\hline 2 & Dian Ayu Retno W. & 70 & 80 & Tuntas \\
\hline 3 & Dian Putri Amelia & 70 & 70 & Tuntas \\
\hline 4 & Diki Lorensyah & 70 & 70 & Tuntas \\
\hline 5 & Eli Novita Sari & 70 & 50 & Tidak Tuntas \\
\hline 6 & Erwana & 70 & 70 & Tuntas \\
\hline 7 & Gini & 70 & 50 & Tidak Tuntas \\
\hline 8 & Giyono & 70 & 50 & Tidak Tuntas \\
\hline 9 & Nita Lestari & 70 & 30 & Tidak Tuntas \\
\hline 10 & Novi Elasari & 70 & 30 & Tidak Tuntas \\
\hline 11 & Nurcholis Masjid & 70 & 50 & Tidak Tuntas \\
\hline 12 & Rengga Setyawan S. & 70 & 60 & Tidak Tuntas \\
\hline 13 & Rosa Ananta R. P. & 70 & 40 & Tidak Tuntas \\
\hline 14 & Ronal Candra A. & 70 & 30 & Tidak Tuntas \\
\hline 15 & Sulasih & 70 & 50 & Tidak Tuntas \\
\hline 16 & Widiya Kurniasih & 70 & 20 & Tidak Tuntas \\
\hline 17 & Yuliana & 70 & 60 & Tidak Tuntas \\
\hline 18 & Zaenal Abidin & 70 & 70 & Tuntas \\
\hline & Rata-rata & & $\mathbf{5 0 , 5 6}$ & \\
\hline \multicolumn{4}{|l}{} \\
\hline
\end{tabular}

Keterangan :

Siswa yang tuntas $\quad: 5$ Siswa $(27,78 \%)$

Siswa yang tidak tuntas : 13 Siswa $(72,22 \%)$

Tabel 2.2

\section{LEMBAR PENGAMATAN GURU DALAM PELAKSANAAN}

\section{PEMBELAJARAN SIKLUS I}

Nama Guru

Nama SD

Kelas

Materi

Hari/Tanggal
: Atik Lestari

: SD Negeri 2 Kauman

: V

: Menyebutkan nama-nama Kitab Allah SWT

: Jumat, 20 September 2013 
Petunjuk : Berilah tanda check $(\sqrt{ })$ pada kolom tingkat kemampuan

yang sesuai dengan indikator pengamatan.

\begin{tabular}{|c|l|c|c|c|c|c|}
\hline \multirow{2}{*}{ No } & \multicolumn{2}{|c|}{ Aspek yang dinilai } & \multicolumn{3}{|c|}{ Tingkat Kemampuan } & \multirow{2}{*}{ Jumlah } \\
\hline & & 1 & 2 & 3 & 4 & \\
\hline 1 & Mengemukakan tujuan pembelajaran & & $\sqrt{ }$ & & & 2 \\
\hline 2 & Melakukan apersepsi & & $\sqrt{ }$ & & & 2 \\
\hline 3 & Membimbing siswa merumuskan masalah & & & $\sqrt{ }$ & & 3 \\
\hline 4 & Membimbing siswa dalam pembelajaran & & & $\sqrt{ }$ & & 3 \\
\hline 5 & Membimbing siswa dalam kelompok & & $\sqrt{ }$ & & & 2 \\
\hline 6 & $\begin{array}{l}\text { Membimbing siswa dalam melaporkan } \\
\text { hasil diskusi }\end{array}$ & & $\sqrt{ }$ & & & 2 \\
\hline 7 & $\begin{array}{l}\text { Melaksanakan metode pembelajaran } \\
\text { kooperatif tipe TAI }\end{array}$ & & $\sqrt{ }$ & & & 2 \\
\hline 8 & $\begin{array}{l}\text { Menggunakan media dan alat peraga secara } \\
\text { efektif dan efisien. }\end{array}$ & & $\sqrt{ }$ & & & 2 \\
\hline 9 & Mengelola waktu secara efisien & & $\sqrt{ }$ & & & 2 \\
\hline 10 & Melakukan refleksi & & $\sqrt{ }$ & & & 2 \\
\hline
\end{tabular}

Jumlah skor $=22$, kategori: $\mathrm{B}$

Kriteria Penilaian :

$$
\begin{aligned}
31-40 & =A \\
21-30 & =B \\
11-20 & =C \\
1-10 & =D
\end{aligned}
$$

Berdasarkan hasil pengamatan dan refleksi pada siklus I ini, dari 18 siswa ternyata banyak siswa belum tuntas, hal ini disebabkan selain teknik pembelajaran yang baru dikenal ternyata banyak siswa yang tidak bersungguh-sungguh belajar dengan pembelajaran kooperatif tipe TAI, banyak yang bermain sendiri. Dari data dan uraian tersebut maka dapat ditarik kesimpulan bahwa pada siklius I dapat diperoleh hasil sosialisasi teknik ini belum dapat diterima oleh siswa sehingga siswa kebingungan 
dalam mengikuti pelajaran. Kemudian adanya beberapa siswa yang belum mendapatkan nilai sesuai dengan standar ketuntasan, hal ini dikarenakan karena teknik pembelajaran yang baru.

Secara garis besar siklus I berjalan baik dan kondusif, walaupun hasil belajar siswa belum mencapai rata - rata 70. Hal ini harus dijadikan suatu yang harus dibenahi dalam pelaksanaan siklus II.

\section{Siklus II}

Adapun dari hasil tes formatif pada siklus II ini, didapatkan hasil sebagaimana terdapat pada tabel berikut ini:

\section{Tabel 2.3}

\section{Hasil tes formatif pada siklus II}

\begin{tabular}{|c|l|c|c|c|}
\hline No & \multicolumn{1}{|c|}{ Nama } & KKM & Nilai & Keterangan \\
\hline 1 & Any Marsela & 70 & 50 & Tidak Tuntas \\
\hline 2 & Dian Ayu Retno W. & 70 & 90 & Tuntas \\
\hline 3 & Dian Putri Amelia & 70 & 80 & Tuntas \\
\hline 4 & Diki Lorensyah & 70 & 80 & Tuntas \\
\hline 5 & Eli Novita Sari & 70 & 90 & Tuntas \\
\hline 6 & Erwana & 70 & 80 & Tuntas \\
\hline 7 & Gini & 70 & 40 & Tidak Tuntas \\
\hline 8 & Giyono & 70 & 40 & Tidak Tuntas \\
\hline 9 & Nita Lestari & 70 & 80 & Tuntas \\
\hline 10 & Novi Elasari & 70 & 70 & Tuntas \\
\hline 11 & Nurcholis Masjid & 70 & 70 & Tuntas \\
\hline 12 & Rengga Setyawan S. & 70 & 90 & Tuntas \\
\hline 13 & Rosa Ananta R. P. & 70 & 60 & Tidak Tuntas \\
\hline 14 & Ronal Candra A. & 70 & 60 & Tidak Tuntas \\
\hline 15 & Sulasih & 70 & 80 & Tuntas \\
\hline 16 & Widiya Kurniasih & 70 & 90 & Tuntas \\
\hline 17 & Yuliana & 70 & 80 & Tuntas \\
\hline 18 & Zaenal Abidin & 70 & 80 & Tuntas \\
\hline & Rata-rata & & $\mathbf{7 2 , 7 8}$ & \\
\hline
\end{tabular}


Keterangan:

Siswa yang tuntas : 13 Siswa $(72,78 \%)$

Siswa yang tidak tuntas : 5 Siswa $(27,78 \%$

Tabel 2.4

LEMBAR PENGAMATAN GURU DALAM PELAKSANAAN PEMBELAJARAN SIKLUS II

Nama Guru

Nama SD

Kelas

Materi

kitab Allah.

Hari/Tanggal

Petunjuk
: Atik Lestari

: SD Negeri 2 Kauman

: V

: Menyebutkan nama-nama Rasul yang menerima

: Jumat, 27 September 2013

: Berilah tanda check $(\sqrt{ })$ pada kolom tingkat kemampuan

yang sesuai dengan indikator pengamatan.

\begin{tabular}{|c|l|c|c|c|c|c|}
\hline \multirow{2}{*}{ No } & \multicolumn{1}{|c|}{ Aspek yang dinilai } & \multicolumn{3}{c|}{ Tingkat Kemampuan } & \multirow{2}{*}{ Jumlah } \\
\hline & & 1 & 2 & 3 & 4 & \\
\hline 1 & Mengemukakan tujuan pembelajaran & & & $\sqrt{ }$ & & 3 \\
\hline 2 & Melakukan apersepsi & & & $\sqrt{ }$ & & 2 \\
\hline 3 & Membimbing siswa merumuskan masalah & & $\sqrt{ }$ & & & 2 \\
\hline 4 & Membimbing siswa dalam pembelajaran & & & $\sqrt{ }$ & & 3 \\
\hline 5 & Membimbing siswa dalam kelompok & & $\sqrt{ }$ & & & 2 \\
\hline 6 & $\begin{array}{l}\text { Membimbing siswa dalam melaporkan } \\
\text { hasil diskusi }\end{array}$ & & & $\sqrt{ }$ & & 3 \\
\hline 7 & $\begin{array}{l}\text { Melaksanakan metode pembelajaran } \\
\text { kooperatif tipe TAI }\end{array}$ & & $\sqrt{ }$ & & & \\
\hline 8 & $\begin{array}{l}\text { Menggunakan media dan alat peraga secara } \\
\text { efektif dan efisien. }\end{array}$ & & $\sqrt{ }$ & & & 2 \\
\hline 9 & Mengelola waktu secara efisien & & $\sqrt{ }$ & & & 2 \\
\hline 10 & Melakukan refleksi & & $\sqrt{ }$ & & & 2 \\
\hline
\end{tabular}


Jumlah skor $=23$, kategori: $\mathrm{B}$

Kriteria Penilaian :

$$
\begin{aligned}
31-40 & =A \\
21-30 & =B \\
11-20 & =C \\
1-10 & =D
\end{aligned}
$$

Pada siklus II siswa sudah mulai mengerti apa yang di intruksikan guru dibandingkan pada siklus I, hal ini dikarenakan guru mengadakan sosialisasi terlebih dahulu sebelum pembelajaran dimulai. Dari hasil belajar siswa terjadi peningkatan kemampuan siswa dalam menyelesaikan soal, terbukti dari 18 siswa 13 siswa (72,78\%) tuntas dan 5 siswa $(27,78 \%)$ tidak tuntas. berarti ada peningkatan kemampuan siswa dalam hasil belajar siswa.

Setelah adanya pengamatan dalam pembelajaran pada Siklus II didapatkan hasil siswa tidak lagi merasa bingung dengan pembelajaran menggunakan metode pembelajaran kooperatif tipe TAI, hal ini dikarenakan guru melakukan sosialisasi terlebih dahulu terhadap siswa. Siswapun sudah mulai fokus terhadap apa yang diperintahkan oleh guru. Sudah $50 \%$ lebih siswa sudah benar dalam menjawab soal-soal tes formatif. Hasilnya pun guru tidak ada lagi kendala dalam mempersiapkan pembelajaran tersebut karena belajar dari pengalaman pelaksanaan siklus I sehingga proses pembelajaran sudah mulai berjalan baik.

Secara garis besar pelaksanaan siklus II sudah berjalan baik. Dari hasil belajar siswa terjadi peningkatan kemampuan siswa dalam menyelesaikan soal, terbukti dari 18 siswa 13 siswa $(72,22 \%)$ tuntas dan 
5 siswa $(27,78, \%)$ tidak tuntas. Berati ada peningkatan kemampuan siswa dalam hasil belajar siswa. Meskipun sudah $50 \%$ lebih siswa yang tuntas dalam mengikuti tes formatif pada Siklus II akan tetapi nilai yang diperoleh belum cukup memuaskan sehingga perlu diadakan Siklus III.

\section{Siklus III}

Adapun dari hasil tes formatif pada siklus III ini, didapatkan hasil sebagaimana terdapat pada tabel berikut ini :

Tabel 2.5

Hasil tes formatif pada siklus III

\begin{tabular}{|c|l|c|c|c|}
\hline No & \multicolumn{1}{|c|}{ Nama } & KKM & Nilai & Keterangan \\
\hline 1 & Any Marsela & 70 & 70 & Tuntas \\
\hline 2 & Dian Ayu Retno W. & 70 & 90 & Tuntas \\
\hline 3 & Dian Putri Amelia & 70 & 80 & Tuntas \\
\hline 4 & Diki Lorensyah & 70 & 90 & Tuntas \\
\hline 5 & Eli Novita Sari & 70 & 80 & Tuntas \\
\hline 6 & Erwana & 70 & 100 & Tuntas \\
\hline 7 & Gini & 70 & 60 & Tidak Tuntas \\
\hline 8 & Giyono & 70 & 70 & Tuntas \\
\hline 9 & Nita Lestari & 70 & 80 & Tuntas \\
\hline 10 & Novi Elasari & 70 & 80 & Tuntas \\
\hline 11 & Nurcholis Masjid & 70 & 80 & Tuntas \\
\hline 12 & Rengga Setyawan S. & 70 & 80 & Tuntas \\
\hline 13 & Rosa Ananta R. P. & 70 & 70 & Tuntas \\
\hline 14 & Ronal Candra A. & 70 & 70 & Tuntas \\
\hline 15 & Sulasih & 70 & 90 & Tuntas \\
\hline 16 & Widiya Kurniasih & 70 & 90 & Tuntas \\
\hline 17 & Yuliana & 70 & 90 & Tuntas \\
\hline 18 & Zaenal Abidin & 70 & 90 & Tuntas \\
\hline & Rata-rata & & $\mathbf{8 1 , 6 7}$ & \\
\hline
\end{tabular}

Keterangan:

Siswa yang tuntas

Siswa yang tidak tuntas
: 17 Siswa $(94,44 \%)$

: 1 Siswa $(5,56 \%)$ 
Tabel 2.6

LEMBAR PENGAMATAN GURU DALAM PELAKSANAAN

PEMBELAJARAN SIKLUS III

\section{Nama Guru}

Nama SD

Kelas

Materi

terakhir.

Hari/Tanggal

Petunjuk
: Atik Lestari

: SD Negeri 2 Kauman

: $\mathrm{V}$

: Menjelaskan Al-Qur'an sebagai kitab suci

: Jumat, 04 Oktober 2013

: Berilah tanda check $(\sqrt{ })$ pada kolom tingkat

kemampuan

yang sesuai dengan indikator pengamatan.

\begin{tabular}{|c|l|c|c|c|c|c|c|}
\hline \multirow{2}{*}{ No } & \multicolumn{2}{|c|}{ Aspek yang dinilai } & \multicolumn{3}{|c|}{ Tingkat Kemampuan } & \multirow{2}{*}{ Jumlah } \\
\hline & & 1 & 2 & 3 & 4 & \\
\hline 1 & Mengemukakan tujuan pembelajaran & & & $\sqrt{ }$ & & 3 \\
\hline 2 & Melakukan apersepsi & & & $\sqrt{ }$ & & 3 \\
\hline 3 & Membimbing siswa merumuskan masalah & & & $\sqrt{ }$ & & 3 \\
\hline 4 & Membimbing siswa dalam pembelajaran & & & $\sqrt{ }$ & & 3 \\
\hline 5 & Membimbing siswa dalam kelompok & & & & $\sqrt{ }$ & 4 \\
\hline \multirow{2}{*}{6} & $\begin{array}{l}\text { Membimbing siswa dalam melaporkan } \\
\text { hasil diskusi }\end{array}$ & & & $\sqrt{ }$ & & 3 \\
\hline 7 & $\begin{array}{l}\text { Melaksanakan metode pembelajaran } \\
\text { kooperatif tipe TAI }\end{array}$ & & & & $\sqrt{ }$ & 3 \\
\hline 8 & $\begin{array}{l}\text { Menggunakan media dan alat peraga secara } \\
\text { efektif dan efisien. }\end{array}$ & & $\sqrt{ }$ & & & 2 \\
\hline 9 & Mengelola waktu secara efisien & & & $\sqrt{ }$ & & 3 \\
\hline 10 & Melakukan refleksi & & & $\sqrt{ }$ & & 3 \\
\hline
\end{tabular}

Jumlah skor $=31$, kategori: A

Kriteria Penilaian :

$31-40=\mathrm{A}$ 


$$
\begin{aligned}
21-30 & =B \\
11-20 & =C \\
1-10 & =D
\end{aligned}
$$

Pada siklus III hampir semua siswa fokus dan memperhatikan materi pembelajaran yang disampaikan guru, hal ini dikarenakan guru mempersiapkan pembelajaran kooperatif tipe TAI secara maksimal. Selain itu pembelajaran kooperatif tipe TAI yang dilaksanakan pada siklus III sudah tidak asing lagi bagi siswa. Dari hasil belajar siswa terjadi peningkatan kemampuan siswa dalam menyelesaikan soal, terbukti dari 18 siswa 17 siswa $(94,44 \%)$ tuntas dan 1 siswa $(5,56 \%)$ tidak tuntas. Berarti ada peningkatan yang signifikan kemampuan siswa terhadap hasil belajar mata pelajaran Pendidikan Agama Islam melalui pembelajaran kooperatif tipe TAI.

Setelah adanya pengamatan dalam pembelajaran pada Siklus III didapatkan hasil siswa sudah terbiasa dengan belajar melalui pembelajaran kooperatif tipe TAI. Sebagian besar siswa sudah fokus mengikuti instruksi yang disampaikan guru dan siswa sudah benar dalam menjawab soal-soal tes formatif. Sehingga guru tidak lagi menjelasakan mengenai pembelajaran kooperatif tipe TAI kepada siswa sehingga hanya fokus terhadap materi yang akan diberikan kepada siswa.

Secara garis besar pelaksanaan siklus III sudah berjalan baik. Dari hasil belajar siswa terjadi peningkatan kemampuan siswa dalam menyelesaikan soal, terbukti dari 18 siswa 17 siswa $(94,44 \%)$ tuntas dan 1 siswa $(5,56 \%)$ tidak tuntas. berati ada peningkatan yang signifikan kemampuan siswa dalam hasil belajar Pendidikan Agama Islam melalui 
pembelajaran kooperatif tipe TAI. Pada siklus III ini sudah dikatakan berhasil baik dilihat dari segi perhatian siswa maupun dari tingkat pemahaman siswa.

\section{Hasil Rekapitulasi}

Hasil rekapitulasi hasil belajar Pendidikan Agama Islam melalui pembelajaran kooperatif tipe TAI.

Tabel 2.7

\section{Hasil rekapitulasi tentang hasil belajar siswa}

\begin{tabular}{|c|l|l|l|}
\hline $\begin{array}{c}\text { Pelaksanaan } \\
\text { Ketuntasan }\end{array}$ & \multicolumn{1}{|c|}{ Siklus I } & \multicolumn{1}{|c|}{ Siklus II } & \multicolumn{1}{c|}{ Siklus III } \\
\hline Tuntas & $\begin{array}{l}5 \text { siswa } \\
(27,78 \%)\end{array}$ & $\begin{array}{l}13 \text { siswa } \\
(72,22 \%)\end{array}$ & $\begin{array}{l}17 \text { siswa } \\
(94,44 \%)\end{array}$ \\
\hline $\begin{array}{c}\text { Tidak } \\
\text { tuntas }\end{array}$ & 13 siswa & 5 siswa & 1 siswa ( \\
$(72,22 \%)$ & $(27,78 \%)$ & $5,56 \%)$ \\
\hline
\end{tabular}

\section{Kesimpulan}

Berdasarkan tindakan yang dilakukan pada siklus I, II, III dan juga dilihat dari hasil tindakan dan hasil belajar yang diperoleh dapat diambil simpulan bahwa metode pembelajaran kooperatif tipe TAI dapat meningkatkan hasil belajar Pendidikan Agama Islam kelas V SD Negeri 2 Kauman Kecamatan kemusu Kabupaten Boyolali.

Hasil belajar siswa kelas V SD Negeri 2 Kauman Kecamatan Kemusu Kabupaten Boyolali meningkat signifikan, itu terlihat dari nilai hasil tes formatif dari siklus I, siklus ke II dan siklus III. Peningkatan ini 
ditunjukkan pada siklus I dengan rata-rata nilai 50,56, pada siklus II ratarata menjadi 72,78, dan siklus III peningkatan rata-rata menjadi 81,67.

Selain peningkatan pada hasil belajar siswa, peningkatan juga diperoleh pada proses pembelajaran. Selama menggunakan metode pembelajaran kooperatif tipe TAI siswa menjadi lebih antusias dan bersemangat dalam mengikuti pelajaran. Dalam pembelajaran, siswa juga lebih memperhatikan dan lebih aktif dalam bertanya maupun dalam menjawab pertanyaan dari guru. Dari kegiatan itu perlu tindakan untuk mempertahankan dan meningkatkan sehingga tercapai hasil siswa yang sangat memuaskan. Hal itu tidak lepas dari peran guru untuk memotivasi dan mempunyai kemampuan untuk memberikan variasi pembelajaran salah satunya melalui sarana dan prasarana yang mendukung pelajaran.

\section{Daftar Pustaka}

Arifin, H.M. 1991. Ilmu Pendidikan Islam. Jakarta: Bumi Aksara. Arikunto, dkk. 2008. Penelitian Tindakan Kelas, Jakarta: Bumi Aksara Dimyati dan Mudjiono. 2002. Belajar dan Pembelajaran. Jakarta: Rineka Cipta.

Hartiny Sam's, Rosma. 2010 Metode Penelitian Tindakan Kelas (PTK). Yogyakarta: Teras.

Huda, Miftahul. 2011. Cooperatife Learning. Yogyakarta : Pustaka Belajar.

Lie, Anita. 2002. Cooperative Learning. Jakarta: PT Grasindo.

Majid, Abdul dan Andayani, Dian. 2004. Pendidikan Agama Islam Berbasis Kompetensi. Bandung: Remaja Rosdakarya.

Mulyasa, E. 2000. Praktik Penelitian Tindakan Kelas. Bandung: PT Remaja Rosdakarya.

Nasution, S. 1982. Berbagai Pendekatan Dalam Proses Belajar dan Mengajar. Bandung: Bumi Aksara. 
Pretami verena, natania , 2012 upaya meningkatkan hasil belajar dan aktivitas belajar siswa dengan pembelajaran kooperatif tipe tai (team assisted individualization) menggunakan alat peraga pada mata pelajaran ipa kelas iv sd negeri rapah 03 banyubiru semester 2 tahun 2011/2012.

Purwanto. 2010. Evaluasi Hasil Belajar. Yogyakarta : Pustaka Ceria.

Savin, Robert E. 2009.Cooperative Learning. Bandung: Nusa Media.

Sayuti, dkk. 2007. Pendidikan Agama Islam. Jakarta: Erlangga.

Slavin, RE. 2010. Cooperative Learning Teori, Riset dan Praktik. Bandung: Nusa Media.

Suyadi. 2010. Panduan Penelitian Tindakan Kelas. Yogyakarta: Diva Press.

http://tarynugrohotappuy.blogspot.com/2013/04/metode-pembelajarankooperatif-tipe-tai.html

http://tarynugrohotappuy.blogspot.com/2013/04/metode-pembelajarankooperatif-tipe-tai.html. Diakses pada Tanggal 1 September 2013. 